\title{
Detective Storyworlds: Longmire, True Detective, and La trêve
}

\author{
Antoine Dechêne, B.A.E.F. Fellow, \\ The Ohio State University
}

\begin{abstract}
:
This paper addresses one question: What makes detective series popular today? In the past, scholars have responded that the genre is mainly focused on plot, to the point of becoming a narrative prototype. This approach explains why detective fiction appears to be more limited in its proliferation across media than other genres such as fantasy or science fiction. If plot is the dominant feature of the genre, and plot somehow works against proliferation, then why are we still producing and consuming so many detective series? Following Marie-Laure Ryan, I wish to argue that a shift from plot to worldbuilding has occurred in detective fiction. This shift follows the evolution of narrative theory which in the last decades had to expand to other disciplines and media. In the same way that narratology embraced the new concept of 'world,' popular series have adopted its potential to proliferate, an aptitude that is now truly part of its aesthetics and poetics. I want to describe and understand the increasingly important role played by storyworlds in detective fiction so as to better apprehend how popular series are made in our cultural era of mass media production.
\end{abstract}

Keywords: detective fiction; Longmire; seriality; storyworld; La trêve; True Detective.

For a very long time, plot has appeared as the dominant feature of detective fiction. Edgar Allan Poe himself already insisted in his 'Philosophy of Composition' (1850) on the importance of denouement and on the raveled structure that should lead to it, that is, narrativity understood as 'purposeful manipulation of expectations' (Ryan 'Narrative' 521). If Poe half-modestly believed that there is nothing extraordinary in unraveling the web of

Crime Fiction Studies 1.1 (2020): 41-58

DOI: $10.3366 /$ cfs.2020.0006

(C) Edinburgh University Press

www.euppublishing.com/cfs 
an investigation he has himself woven in the first place, he nonetheless created a narrative structure that has now turned into a prototype. It is no coincidence, moreover, if Poe's Dupin stories are set in Paris. The French capital was indeed, along with London, ${ }^{1}$ one of the most densely populated cities of the nineteenth century. It is the place where the flaneur wanders before being dragged away from the protection of the arcades and become overwhelmed by the speeding flux of the human crowds. He then makes way for the detective figure who is equipped with the necessary ratiocinative tools to read and interpret the many mysteries and crimes he has to face. ${ }^{2}$

Dupin's stories could not have taken place somewhere else. The same thing can be said about most detective series produced in the past thirty years. Accordingly, this paper focuses on the worlds in which contemporary detective plots are set. This approach will reveal the glocal (global and local) nature of detective fiction in the field of world studies as well as the current influence of the Nordic Noir on the genre. It will also highlight the metacognitive dimension of contemporary detective TV series, which reject the possibility of intellectually and emotionally gratifying closure. Rather, most detective stories discussed here - if they still offer a solution to the crime mystery - point at questions that are far more difficult to answer.

In this perspective, this essay first discusses the narrative interest of plots versus storyworlds in detective fiction. The relatively new focus on storyworlds leads to the analysis of the genre's development as a serial form. The third section then further examines the notion of 'Glocalisation' through the example of Craig Johnson's Walt Longmire series before offering closer readings of two detective TV shows: True Detective (HBO 2014-) and La trêve (RTBF 2016-2018). The last analyses deal at length with the metacognitive qualities of these series which, again, are not content with the simple exposition and resolution of a crime, but rather, are obsessed with the impossibility of finding reliable truths and are thus far bleaker and confusing than traditional whodunits. On the whole, this paper should help understand the growing interest in detective storyworlds, their impact on the crime plots, and their narrative potential, which, in turn, may shed a different light on the ongoing success of the genre.

\section{Plots versus Storyworlds}

This paper addresses one key question: Why do we still read/watch detective series? A common scholarly response consists in saying that the genre's success lies in its propensity to generate suspense, curiosity, and surprise. Detective fiction, as it were, can be apprehended as a 'prototype' of plot-centred narratives (Brooks; Sternberg; Baroni Tension; Ryan 'Cheap'). This point of view may explain why the genre appears to be more limited in its proliferation across media than other genres such as fantasy or science fiction. 


\section{Detective Storyworlds}

If plot is the dominant feature of the genre, and plot somehow works against proliferation, then why are we still producing and consuming so many detective series? This paper argues that a shift from plot to worldbuilding has occurred in detective fiction. ${ }^{3}$ This shift parallels the evolution of narrative theory which in the last decades had to expand to other disciplines and media (Ryan 'Texts' 11). In the same way that narratology embraced the new concept of 'world,' popular series have adopted its potential to proliferate, an aptitude that is now truly part of its aesthetics and poetics.

Another theoretical consensus about crime fiction (especially in its serial form) is that its interest lies in the revisiting of a familiar world about which one knows much, but not all. This is, of course, what Eco explains in his famous paper on 'Innovation and Repetition;' for him, 'the reading of a traditional detective story presumes the enjoyment of a scheme' (Eco 162). Crimes and investigations nearly become pretexts. What the public loves, Eco adds, is to 'continuously recover, point by point, what they already know, and what they want to know again' (164). This is why there are series; pleasure comes from repetition. But what readers and spectators particularly love, probably even more than the recurrence of a narrative scheme, is returning to the world of the stories they are so familiar with, that is their storyworld.

What then is a storyworld and how does it relate to plot? In essence, a storyworld is 'an imagined totality that evolves according to the events in the story' (Ryan 'Texts' 13). The concept is rather broad since 'it covers both factual and fictional stories, meaning stories told as true of the real world and stories that create their own imaginary world, respectively' (Ryan 'Story' 33). By comparison, the plot is the modification of a character's world. In its minimalist definition, the plot is a chronological chain of events (Abbott 240), but it can also be understood as 'a rhetorical device whose primary function is to arouse a "cognitive desire" for a possible ending' (Baroni 'Many' 2). Plot is a more abstract notion than story - understood as a mental construct implying a world (Ryan 'Texts' 23) - since different stories can have the same plot.

Frequently associated with science fiction, fantasy, and horror, the concept of storyworld has rarely been applied to detective fiction, considering that the genre gives prominence to plot and denouement ${ }^{4}$ rather than to characterization and worldbuilding. Contemporary detective series, following the example of numerous serial narratives produced today, have had an increasing and ongoing interest in the development of complex storyworlds. In other words, I believe that the audience's interest does not solely lie in the unravelling and resolution of a plot, but also in the immersion in a world they like.

Indeed, I want to go against the consensual idea according to which detective fiction is mainly (if not only) about plot. Marie-Laure Ryan, when trying to define narrative prototypes, has shown that mystery stories and thrillers are the best examples of 'narrativity as purposeful manipulation of 
expectations' ('Narrative' 521). She does not believe that narrativity solely lies in plot, but if it were so, as scholars such as Sternberg or Baroni have argued, then detective fiction would be a narrative prototype. Baroni, however, is more nuanced than Sternberg since he acknowledges that contemporary series are now more interested in building worlds with narrative potential than in elaborating intricate plots. The two are not necessarily antipodal, as he explains:

If the story seems to be subordinated to the world that contains it, it is not because in serialized or franchised narratives, the plot has been relegated to a second level, but rather because these narrative forms subordinate the weaving of a plot to the potentialities inscribed in the storyworld, which in itself is not contradictory with the development of an effective plot (Baroni 'Intrigues' 35-6; my translation).

Storyworlds and plots work together in the serialisation process. While the expansion of the storyworld in detective fiction enables the creation of the series themselves, detective plots remain essential in order to produce specific novels, episodes, and/or seasons.

The question of storyworlds points at the larger issue of the sources of interest of serial narratives. In a 2015 article, Ryan classified the different 'sources of interest' of narratives into three, not mutually exclusive, categories: world, plot, and medium ('Texts' 25). I believe that a fourth category is necessary: characters. Generally speaking, Ryan considers that characters are part of the plot because there would be no events without them. But in a footnote to her diagrams, she remarks that this category could easily be created in order to include narratives with vivid protagonists 'whose ability to arouse emotions transcend the plot' ('Texts' 27). In fact, this paper follows Suzanne Keen's argument that characters straddle the boundary between plot and world (Keen 298). This is particularly the case in detective fiction in which most serial narratives are richly developed around the central figure of the investigator, his/her partner, or his/her work team.

In a related way, James Phelan and Peter J. Rabinowitz have explained that audiences are interested in and respond to three different components of narratives: the mimetic, the thematic, and the synthetic. These components imply different responses from the audience:

Responses to the mimetic component involve readers' interests in the characters as possible people and in the narrative world as like our own, that is, hypothetically or conceptually possible and still compatible with the laws and limitations that govern the extratextual world. These responses to the mimetic component include our evolving judgement and emotions, our desires, hopes, expectations, satisfactions, and disappointment. Responses to the thematic 


\section{Detective Storyworlds}

component involve readers' interests in the ideational function of the characters and in the cultural, ideological, philosophical, or ethical issues being addressed by the narrative. Responses to the synthetic component involve an audience's interest in and attention to the characters and to the larger narrative as artificial constructs, interests that link up with our aesthetic judgements. (in Herman et al. 7)

The audience's interest may vary and favour one component over another depending on the type of narrative, but usually interests are mixed and interrelated. Characters are also made of these three components. They 'do resemble possible people, they are artificial constructs that perform various functions in the progression, and they can function to convey the political, philosophical, or ethical issues being taken up by the narrative' (in Herman et al. 111). On the whole, the two critics argue, it all comes down to what the audience feels drawn to in the first place: 'If you are interested in how the shapes of actions in literary texts reflect or influence reality [...], then plot is clearly more important. If you are interested in literature as a window into psychology, then character is more important' (in Herman et al. 112). This, however, seems too vague an answer, even when one specifies that the relative importance of plot or character varies according to the progression of the narrative itself (in Herman et al. 112).

\section{Serial Detectives}

In contemporary detective series, characters do not serve a purpose or predefined role as it arguably used to be the case. Their thematic component is not as clear-cut and easily identifiable. Detective figures, for instance, are not only there as surrogate readers, whose only role is to identify and interpret clues for the audience shadowing them. Their role evolves with the narrative: they can be reliable investigators, but they can also become victims, criminals, or even be all three at once. ${ }^{5}$

Again, character is a useful category to help fill the gap between plot and world. Nothing would happen without them and storyworlds would remain desperately empty. Moreover, the unity of a series can often be associated with a set of characters rather than their actions. The accumulative logic of series asks for a more dynamic and open model which not only undermines the conception of plot as a fixed, global structure, but also challenges the possible ending of the narrative. For Baroni, in the very 'logic of its genesis, serial narrative resembles more our daily lives' 'natural' plots than the 'artificial' ones in narratives whose scheming is too obvious or apparent' (39; my translation). Conscious of these tendencies, detective-series writers and producers have worked steadily to counterbalance the dominance of plot by proposing ever more detailed settings and vivid characters. This is already what 
Karin Danielsson acknowledged in her 2002 dissertation on seriality and contemporary literary detective fiction, insisting on the key role played by the detective protagonist and his/her personal life:

A contemporary detective series typically has a recurring protagonist who is depicted as existing in a world which goes on between books, a world in which actions in book number one have an effect in books number two and three. There are numerous references to events that have taken place in and between earlier instalments, both regarding earlier 'cases' and regarding developments in the protagonist's personal life, such as love stories, illnesses, family and other relationships. Contemporary serial detective fiction frequently foregrounds the protagonist's life at the expense of the cases she or he investigates. Seriality also demands an ambition towards realism in relation to intradiegetic time. (Danielsson 13-14)

Danielsson's argument is key to understand the way detective series are produced today. Accordingly, one has to distinguish 'classic' detective series such as Sherlock Holmes, in which previous events rarely have any consequences for later cases, from contemporary series like Longmire in which we are constantly reminded of what happened to the eponymous sheriff as well as to his associates, his family and friends. The set of characters affords endless variations for new stories and mystery plots. The insistence on the protagonists' private lives is also particularly relevant because in many cases the detectives find themselves personally implicated in their own investigations. Borrowing much from the thriller, some series present fragile protagonists, whose world is threatened by evil and who can be irreversibly harmed. Longmire himself is often injured and, although he remains very much a tough guy, he also suffers from different traumas (his wife's death, the Vietnam War, the death of his lover who also happened to be the criminal in The Cold Dish, etc.).

So far, the question of why people still read/watch detective series has implied the broader issue of the audience's multiple interests in narrative. The main argument has been that the interest of detective series - whether mimetic, thematic, or synthetic - resides in the exploration of a storyworld populated by recurring characters whose adventures enable the production of specific novels, episodes, or seasons. But is that all there is? In other words, is character the only thing needed to maintain a series? I wish, here, to briefly discuss the example of a series which does not pertain to the genre but which is relevant because it has proved resilient despite the progressive disappearance of approximately all its original characters: The Walking Dead (AMC 2010-). Now reaching its tenth season, the show seems to make a point in reflecting that its universe, regardless of its inhabitants, is by itself enough to keep producing new seasons. Of course, one has to keep in mind, as Frank Kelleter observes, 


\section{Detective Storyworlds}

that The Walking Dead remains popular in the sense that '[a]s in most evolutionary processes, success only means avoiding disappearance, not reaching a final state of fulfilment' (Kelleter 14). This example confirms what Jean-Pierre Esquenazi already explained about serial narratives, namely that the idea of a series often comes down to an atmosphere or a situation (Esquenazi 97).

In this perspective, an interesting task would be to establish a sort of a typology of recurring motifs that shape detective storyworlds today. If the genre has seemed to be based on immutable rules for nearly two centuries, its enduring popularity cannot solely be explained by a desire for 'redundancy' (Eco 165), but more precisely by the very tension between 'innovation and repetition' that gives Eco his title. This is also the argument made by the editors of Serial Crime Fiction (2015). The volume's purpose is to address the issue of seriality in the field of crime fiction through a rhetorical approach to demonstrate that:

[N]ot all series, or episodes of an individual series, develop according to the same structural pattern. The centre of the narrative may be the detective, the place, the social setting or timeframe; the medium may be print, film or television; some series transition between these. Form and content are flexible, not limited or limiting: our argument is that what ultimately distinguishes the series is the tension between sameness and difference, familiarity and strangeness, repetition and progression. In crime series that present this tension, the familiarity of situations that create cosiness is challenged by change, surprise and novelty that may come from the evolution of the detective, or the setting, the different historical periods, the protagonist's personal story, or the fact that in each story different social and political issues are tackled; or again, because the genre successfully expands its boundaries to other genres or genders. (Anderson, Miranda and Pezzotti 4; my emphasis)

So what is the same and what is different? The major point made by the three editors is that repetition seems to be related to plot, whereas innovation comes from the detective's personal life, the setting, or the socio-political context of the narrative, that is its storyworld. The synthetic component and the importance of the medium seem rather secondary. ${ }^{6}$ The mix of genres is another interesting aspect of detective fiction which, since the very beginning, has never stopped flirting with the Gothic, horror, adventure, romance, but also the fantastic and, of course, comedy. Now, one may ask: if detective fiction has always been characterised by a tension between familiarity and novelty, what makes it different today? Especially regarding its serialised form - which was already the case for the Dupin, the Holmes, the Poirot, the Spade or Marlowe stories - when does this growing interest in storyworlds take place? 
An important turning point in the history of the genre certainly occurs with Georges Simenon's creation of Jules Maigret. Simenon's novels and short stories have relegated the mystery plot and crime investigation to a secondary level. Its readers do not open a new book to discover 'who done it', but rather to follow their favourite commissaire as he wanders through the streets of Paris and has nice meals with his wife. Maigret, as it were, has mostly been praised for the complex psychology of its characters, thereby exemplifying Phelan's statement that if one is interested in psychological matters then one should be more interested in characters than in plot.

What has changed since Maigret, however, is the ramification of the storyworlds which enable the creation of series. While plots remain essential to produce relatively closed stories, storyworlds engender a greater diversification of narrative potentialities. Simenon's work is a good example that a storyworld populated by a rather small set of characters (mainly his wife and colleagues) can already lead to a gigantic series (approximately seventy-six novels, twenty-eight short stories and countless adaptations in other media from radio to comics to movies to television) only loosely concerned with criminal issues.

The serialisation process is slightly different today. The production of detective-fiction series does not only include distinct series set in specific storyworlds; it also entails the various phenomena of adaptations, reboots, prequels, sequels, and anthology series. The latter, emblematically actualised by shows like True Detective or Fargo, further verify Esquenazi's intuition that the idea of a series can be reduced to an atmosphere or a situation in a particular socio-political context. The sense of coherence and consistency of such series does not come from a shared storyworld, but from something more diffuse and hard to define. In the case of True Detective, the concept of storyworld might clarify why the audience was so disappointed by season 2 in comparison with seasons 1 and 3, but does not explain the cohesion and ways of apprehending an anthology series. I will come back to this issue in the last section of this paper.

\section{Detective Fiction and Glocalisation: Longmire}

To analyse the developments of detective storyworlds, I want to examine the cases of some of the most thriving serial narratives at present: Craig Johnson's Longmire series as well as True Detective (HBO 2014-) and La trêve (RTBF, Netflix 2016-2018). ${ }^{7}$ Johnson's work is particularly relevant here since he has written no less than seventeen novels and a collection of short stories in the past fifteen years, all dedicated to their eponymous Sheriff of Absaroka County, Wyoming, Walt Longmire. The series has also been adapted on television and is now in its sixth season distributed by Netflix. Furthermore, Longmire has become a brand with its tie-ins and derived goods and is the subject of several fan platforms, most notably on Facebook and on crime-fiction blogs. 


\section{Detective Storyworlds}

Johnson's œuvre serves as a perfect example of a series based on a storyworld inspired by the everyday life of the novelist, himself a rancher at Ucross in Longmire's own home state of Wyoming. This far-Western world is populated by a variety of recurring characters (the sheriff's Cheyenne friend Henry Standing Bear, his daughter Cady, his colleague and lover Vic, the office dispatcher Ruby, Dorothy, owner of the Busy Bee Cafe, his mentor Lucian Connally, etc.) who all participate in the specificity of the storyworld, which in turn contributes to the longevity of the series. Indeed, if each novel/episode introduces a new crime/mystery to be solved, what Longmire fans especially like are the characters' personal stories and the vast Western setting. Some fans have even gone as far as 'exploring Longmire's country' by visiting the places that have inspired the series's universe and since 2015, the town of Buffalo, Wyoming, has hosted the Longmire Days, a four-day festival entirely dedicated to Johnson's storyworld. ${ }^{8}$

The remote setting, especially, enables Johnson to dissect small communities in which everybody is a suspect. It offers an immersion in a world similar to ours, but with a hint of exoticism, which in Baroni's view, remains an essential characteristic of storyworlds, enabling their proliferation and commercial success ('Intrigues' 46). Faraway places and distant communities present a glimpse into the alien and the unknown. They reflect the complexity of our world while revealing a society in which appearances are often deceptive. Olivia Kiernan recently published on Crimereads about the attraction of setting a detective series in such places:

For the writer, there is nothing more attractive than setting a mystery in a small town. Whether it's a character called back to their hometown to re-discover all the reasons they left in the first place ${ }^{9}$ or a newcomer who at first doesn't understand the town rules but soon gets sucked into some dark mystery, ${ }^{10}$ there are many reasons for choosing a tight-knit community as a setting to our dastardly plots. For the reader, you get to enjoy a variety of settings: a frozen Swedish forest or the sweeping, dry heat of the outback. Small towns have plenty of murderous secrets, within the pages of crime fiction if nowhere else. (Kiernan n.p.)

As such, these detective-fiction settings emphasise the genre's own participation in a bigger 'world' narrative. In the light of examples such as Twin Peaks, Top of the Lake, Broadchurch (and adaptations Gracepoint in the US and Malaterra in France), Sorjonen (Bordertown), and, of course, True Detective (seasons 1 and 3) and La trêve (The Break), one can understand some of the multiple interests of such foreign settings.

The first of these is economic. Detective fiction as a genre appears as a 'glocal' phenomenon in the field of world studies. 'Glocalisation' is a concept introduced by David Damrosch to account for a peculiar 'mode of literary 
creation and circulation' (Nilsson, Damrosch and D'haen 4) that combines 'global patterns with local themes' (14). The glocal nature of detective fiction lies in some of its distinguishing features such as the importance of the detective figure enabling the recognition of the genre worldwide, the marketing and translation issues related to its distribution, and the adaptations and appropriations by different cultures and media. Detective fiction, at least in its most classical whodunit or hard-boiled forms, is 'glocal' because it exports 'local situations abroad' and imports 'global situations at home' (20). It is both stylized (based on a shared and recognizable set of rules) and localized (located in a particular place and time, rooted in the social and cultural contexts of the different countries where it develops). Detective fiction is an indefinitely malleable structure that can be used by any writer in any country. In many series, the stories are the same; the world and its inhabitants are different.

The second interest is thematic. The isolated settings diverge from the traditional urban landscape usually associated with detective fiction. They reveal an aspiration for more 'natural' plots and characters (Baroni 'Intrigues' 39), reflecting the detective's existential doubts and troubled identity, the complexity of the human psyche, the lack of clear borders between good and evil, and the multiple ways of apprehending reality and time. In the Longmire series, the apparent immensity of the American West encourages introspection and tints the narrative with spiritual, almost mystical overtones. The sheriff indeed often has prophetic dreams and visions stimulated by his long-standing friendship with his comrade Standing Bear. The land shapes these two men, whose ecological sensibilities are an essential part of their detecting methods which, if they help them solve the criminal cases at hand, also raise existential questions that are far more difficult to answer. ${ }^{11}$

\section{On a Closer Look: True Detective and La trêve}

True Detective season 3 spans 30 years. There are the crimes and first investigation in 1980, then the reopening of the case in 1990, and the conclusion in the early 2000s. The scenario centres on a detective's obsession for an unsolved affair involving a child's murder and another one's disappearance. Little Will Purcell is found dead in a cave and his sister Julie is missing. Unable to find her, Wayne Hays (Ali Mahershala) loses his position as a field investigator until his former partner wants him back on the job in 1990. Discoveries are made, but the young woman is still nowhere to be found. Ten years later, the two men, now retired, are back in business when Wayne agrees to talk about the case for a TV programme about unsolved mysteries. Wayne now suffers from Alzheimer so when he eventually and accidentally finds Julie Purcell and even talks to her, he has forgotten what he is looking for, thereby only reaching unsatisfying personal catharsis. 


\section{Detective Storyworlds}

In La trêve season 2, a rich aristocrat is found dead in her swimming pool, her throat cut. Yoann Peeters (Yoann Blanc) who had sworn never to investigate again cannot resist his former psychiatrist Jasmina's call for help. She is convinced that the main suspect, Danny, another patient, is innocent and she wants to save him. Trusting her, Yoann nearly loses his mind trying to prove the impossible since the suspect is in fact guilty. The three of them are caught in a love triangle that turns the roles of the victim, detective, and criminal upside down.

In terms of setting, True Detective 3 takes place in the Ozarks Mountains of northwest Arkansas. La trêve is set in Gaume in southeast Belgium. The Ozarks, with its forests and numerous lakes, rivers, and waterways, creates an intriguing, mysterious, if not metaphysical scenic landscape that reflects the detective's own state of mind. This is also the case of the Belgian Ardennes region, which provides a shadowy panorama made of clouds and trees filtering light only to let a few clues appear. The Ardennes is also arguably one of the only wild spaces left in the country.

The connection between setting and protagonists is established in a particularly striking way in the two series' opening credits. To understand this, one only has to compare the aesthetics, editing, and music of these credits. In both, the mix of pale and dark tones (reds and dark blue in True Detective, a dominant of black and greens with red flashes in La trêve) highlights the haziness and morbid intricacy of the drama as well as that of the two main detectives whose gradual mental instability contributes both to the problem and the solution of the mystery. The music of the opening credits is somehow similar in the two shows. The two songs, Cassandra Wilson's interpretation of 'Death Letter,' a classic delta blues originally sang by Son House and 'True Love' by the Belgian rock band Balthazar, impart a haunting, eerie mood to the series on top of working as intimations of the mysteries. They also foreground the slow pace of the investigations that seem to have adopted the rhythm and introspection spurred by nature rather than by big cities.

Longmire, True Detective, and La trêve are also characterised by a conspicuous lack of high technology. In direct contrast with the various CSIs - which only had a limited interest in storyworlds; after all New York, Las Vegas, or L.A. are interchangeable - the three series present stories either set in the past or in places that do not have access to lab technologies. The investigation in True Detective 3 starts again in the 1990s because the police are now able to trace back fingerprints to Julie Purcell. Similarly, the police in La trêve never have the appropriate technology to analyse evidence, leaving the inspectors to their own devices. Longmire insists on time-consuming drives and long waits for test results (ballistics, DNA, etc.). The sheriff himself does not have a cell phone and barely knows how to use a computer. And even if he 
knew how, Walt often humorously remarks, there is no cell or Internet service in his part of Wyoming anyway.

Further thematic and synthetic components of the credits warn the audience that appearances are deceptive and that they should be prepared to face ambiguities sometimes hard to resolve. As already suggested, the two shows' fundamental ambivalences are part of a larger process of incorporation of metacognitive features within more mainstream crime fiction. The credits of True Detective open on a vast misty landscape right before introducing Wayne Hays, his head photographically superimposed on a woodland scenery. Another striking image of the detective exposes him with the face diagonally cut in half, the right eye staring at the audience and the rest of the face exposing a cloudy sky and dead trees. In the last shot of the credits, a sunset is glowing through the detective's head. These different stages point at Hays's professional and personal evolution. He is first presented as a young inspector disoriented in the forest where the body was found; then as a frustrated midcareer policeman who has lost his badge because he was unable to solve the case; and lastly, as a retired old man whose mind is haunted by the case and by a gradual loss of memory which, paradoxically, also hints at the final revelation and a possible coming to peace with himself.

The opening credits of La trêve take the form of a Rorschach test that creates a fascinating kaleidoscope effect which doubles the characters' faces over a raven background. The mirroring pattern instantly points at the secrets, but also the madness looming behind their behaviours. ${ }^{12}$ The gauziness and translucence of the faces, like open wounds revealing dark forests, proposes an aesthetic vision complementary to that of the American series. The metaphysical dimension of both credit sequences is also signalled by the image of Christ in True Detective and that of the victim floating like a bloody angel above the Belgian countryside in La trêve. Finally, the two shows' advertising posters share interesting features. The HBO poster exposes Hays looking back at the audience through a dirty glass blurred by the rain and trees in the background. The RTBF poster displays a profile of Yoann Blanc, eyes closed, with light shining on his face and with the whole back of his body made of a black, horizontal forest. The message is similar: the two series are based on tortured men surrounded by trees, digging for their roots, searching for themselves.

Overall, the visual effects and the 'transparency' (open wounds, men torn in two) of the characters reveal that, in both series, the main mystery is located on the inside. The image of the brain and synapses that turn into expanding tree roots, like a labyrinth of forking paths, points at the intricacies of the detective's cognitive task. On the verge of madness, both Hays and Peeters see ghosts who help them solve the cases. Old Wayne still talks to his dead wife, a former teacher and writer who published about the case. It is only when he finally decides to read her book (another metacognitive leitmotif) that he eventually 


\section{Detective Storyworlds}

finds the solution (even if he forgets about it because of his Alzheimer's). Similarly, Peeters is haunted by the ghost of his former colleague, the inspector Sébastian Drummer who was shot in front of him at the end of season 1. The two detectives have nightmares and are haunted by visions that are a burden threatening their identities, but also premonitions guiding them towards the resolution of the investigation.

Again, the remote and secluded locations mark a sharp contrast with the traditional urban setting associated with detective fiction. Yet, the settings' thematic component remains more or less the same: in a hard-boiled fashion, it highlights the heroes' own isolation and endless struggle with an immoral society and the police hierarchy. In both seasons of La trêve, for instance, the local communities have to deal with invasive industrialisation through the symbolic construction of a dam in season 1 and a highway in season 2, two forms of colonialism that provide the general background in which the actual murders happen. These events also highlight the 'glocal' dimension of the show through the intrusion of global issues and their consequences on very localised situations.

The shows have yet more in common. In both, the investigators are debarred from the police force because they are mentally unstable and too obsessed with the cases at hand. In both, representatives of the law are depicted as careless, corrupt, and even criminal. The detectives themselves become criminals since they are responsible for the deaths of key witnesses. The stories also insist on the protagonists' family lives and personal relationships linked to the mystery. Wayne's wife has been leading her own enquiry in order to write her books and his son, himself a cop in the third section of the story, helps him with the TV interview and the case's conclusion. As for Peeters, he is deceived in both seasons by his lovers (the first one is the criminal and the second the final victim). Both detectives struggle with solitude, madness, and death. In the end, what the audience really wants to know is not whether they are going to solve the cases, but if they are going to make it at all. Wayne and Peeters, at the same time strong and insecure male figures living in a society that both needs and rejects them, embody the main source of interest of the series. The Ozarks and Ardennes landscapes, along with their socio-political context, contribute to the 'glocal' character of the series.

Many critics see in these developments the influence of the Nordic Noir which, for the past twenty years, has become a paragon of global detective fiction (see for instance Avis; Piper; Hansen and Waade). Paige M. Piper, especially, provides an enlightening definition of the genre. For her,

Nordic Noir is an umbrella term for the moody, atmospheric crime fiction produced by Scandinavian countries, generally featuring characters and situations that are morally complex, with intimate personal portrayals of 
protagonists functioning within close-knit communities and small towns. The works highlight the exoticism of the landscape and weather of Scandinavia. (Piper 19)

Contemporary detective series are indeed characterised by a form of dark realism, isolated and desolated places and gloomy, even depressed detectives (men and women alike). Locations in particular, with their specific climate, have become characters in their own right, reflecting the personalities of their inhabitants. Accordingly, a geographical location or an atmosphere can very well define a series. Stories and plots are often similar; only the storyworld and characters change. On the whole, as Danielsson already pointed out:

Seriality can nowadays be perceived not only in the repetition of characters or setting, but in the treatment of structure, suspense, and closure as well. Characters in contemporary detective fiction are not complete and fixed in book one and ever onwards, but develop and change in time with their narrative communities, and often in time with the real world as well. Writers work at creating and sustaining intertwined subplots, minor characters, and settings that support and promote a dynamic protagonist. It is especially intriguing to notice that such mainstays of genre conventions as suspense and closure can be, and are, affected by seriality to a discernable degree, without this seemingly threatening the genre. (173)

Danielsson's model still works today and, I believe, explains the ongoing success of serial crime fiction across different media. Again, the Longmire series is a case in point. Like a Simenon fan who opens another Maigret, Johnson's audience is looking forward to beginning a new novel or watching the next episode because of the storyworld which holds the series together. Maigret is set in a European capital populated by a small set of recurring characters, the Longmire stories take place in the vast American West of diverse and dispersed communities which all offer new worlds to explore and thus more content for subplots. As Johnson himself jokingly confessed in an interview, ${ }^{13}$ he has enough material for the series to go on forever, or at least until he or Walt dies.

\section{Conclusion}

What Danielsson's thesis does not touch upon, however (but again she was writing in 2001 and only about literature), is the anthology format developed by series such as Black Mirror (2011-) or True Detective. ${ }^{14}$ One question thus remains to be asked: can storyworlds account for the success of such series? In the case of True Detective, on the season level, for all the reasons that I have developed so far, the answer would seem to be yes. Yet on the macro level, there is something more that provides a sense of cohesion for a series to be 


\section{Detective Storyworlds}

called series under a single title. If a series is 'a form that repeats, theoretically ad infinitum, the same kind of action in roughly the same narrative space or time-slot, featuring at least one character continuously throughout' (Priestman 50), what do the seasons of True Detective repeat? The answer to this question can be found in the bad reviews season 2 received. ${ }^{15}$ Indeed, what most critics and fans did not like about that show was its lack of character development and, above all, its urban Californian setting. In other words, season 2 appeared as much more conventional than its counterparts. It lacked the grimness and metacognitive dimension of the first season. The initial success of True Detective mostly depended upon the morose and sweaty Louisiana decor as well as on Rust Cohle's (Matthew McConaughey) pessimism and metaphysical soliloquies. In brief, season 1 had an atmosphere that the audience simply could not find in the next. This is what season 3 tried to recover: an isolated rural place, a small secretive community, and detectives struggling with a crime mystery while also dealing with their own personal insecurities.

Contemporary detective series have a taste for grim and mysterious storyworlds. The natural setting contributes to and reflects the shows' melancholic atmosphere. They also enhance the 'sense of the cinematic' characterizing so much of the latest televisual production. Series such as True Detective and La trêve share the tone and rhythm of the Nordic Noir which, according to Glen Creeber, 'can be defined by a rather slow and understated pace, the dialogue often sparse, monosyllabic and the lighting frequently muted. While there is clearly action (it is, after all, part of the crime genre), its drama also allows for long moments of stillness and reflection' (Creeber 24-5). The repetition, then, comes not only from a specific storyworld, but from a repeated set of characteristics borrowed from the Nordic Noir and transposed to different places and characters in a glocal pattern. The detective storyworlds thus created share a similar taste for the representation and understanding of the human condition in a context of global uncertainty.

Overall, this paper tried to open different avenues of reflection on why and how detective series have developed a growing interest in the creation of intricate storyworlds to ensure their proliferation. This relatively new aspect of the detective genre does not replace the plot dominant, but rather complements it, presenting evolving worlds with characters whose doubts and questions reflect that of real life. Plots are still essential to produce distinct episodes and seasons, but settings and complex characters (who can suffer irreversible harm) are truly what most contemporary (detective) series are about. If some may go on forever, most of them do not because their protagonists either die or have to face irresolution. While The Walking Dead squeezes the potential of its storyworld to the last drop, Longmire, True Detective and La trêve 


\section{Crime Fiction Studies 1 (2020)}

reveal that a series' interest does not necessarily lie in infinite replicability, but in a sound balance between worldbuilding and plot, with a twist of existential doubt.

\section{Notes}

1. Of course, 'The Man of the Crowd' (1840) was already taking place in London.

2. For an extensive analysis of the evolution of the figure of the flaneur see, for example, Dana Brand's book (Brand), Mary Gluck's article (Gluck), or my own work (Dechêne).

3. We will see that this shift also corresponds to the growing international success of a new approach to detective fiction: the Nordic Noir and its first ambassadors Maj Sjöwall and Per Walhöö's Martin Beck series (1960s-70s) followed by Henning Mankell's Kurt Wallander series (1990s-2000s). For a more detailed study about the origins of Scandinavian crime fiction see Barry Forshaw's book (2012).

4. Again, Poe was the first one to claim about 'The Murders in the Rue Morgue' that there is nothing 'ingenuous' in 'unravelling a web which you yourself (the author) have woven for the express purpose of unravelling' (Poe n.p.).

5. In that sense, one could argue that recent detective productions have fully integrated the potentialities of the genre's 'metaphysical' or 'metacognitive' branch which, since stories such as 'The Man of the Crowd,' has exposed the darker, often unsolvable, side of the investigator's cognitive task. For a detailed discussion of metacognitive mystery tales see Merivale and Sweeney's foundational volume (Merivale and Sweeney) or my own recent book (Dechêne). The new series Absentia (2019-), staring Stana Katic (Castle) as Emily Byrne, an abducted FBI agent who was tortured for six years and possibly transformed into a merciless murderer, is a good current example of a character embodying the three roles of victim, detective, and criminal in one.

6. The Longmire series, for instance, reveals that fans may have entered Johnson's storyworld through the books or the TV show, but like to switch between the two and appear to appreciate them equally.

7. For the sake of this paper, I will only focus on the last seasons of True Detective and La trêve, which, from the opening credits onwards, definitely share mimetic, thematic and synthetic components.

8. To explore Longmire's country see the website: http://ourstreamlinedlife.com/exploringlongmire-country/ and the Longmire Days official page: http://buffalowyo.com/longmiredays For a discussion of the concept of 'cultural tourism,' see Even-Zohar's article (Even-Zohar, Feijó and Monegal 18-9).

9. Very recent examples include Sharp Objects (2018) or the second season of The Sinner (2017-).

10. Typically in Broadchurch and La trêve, but also in the French Meurtres à (2013-2017) in which each episode takes place in a different town or region.

11. For a more detailed analysis of the role of landscape in the Longmire novels see the paper that I co-wrote with Luca Di Gregorio "'Knock It off with the Mystical Horseshit": Detection in the American West' (2018).

12. The symmetrical effect also recalls the 'two-faced Janus' (Borges 120) that Lönnrot discovers at the Villa Triste-Le-Roy in 'Death and the compass,' one of the most emblematic metacognitive mystery tales.

13. Luca Di Gregorio and I interviewed Craig Johnson in Brussels for the 2018 Boulevard $d u$ Polar (http://www.boulevard-du-polar.be/rencontres-2018/). Unfortunately, the interview was not recorded or transcribed. 


\section{Detective Storyworlds}

14. Another striking example is American Crime (2015-2017) which has the same actors playing different roles in the three seasons, thereby highlighting its synthetic component while also creating ontological metalepses that increase the drama's confusion.

15. See, for instance, the quite straightforward RollingStone article 'What Went Wrong with True Detective Season 2?' (https://www.rollingstone.com/tv/tv-news/what-went-wrong-with-truedetective-season-2-67286/)

\section{Works Cited}

Abbott, H. Porter. The Cambridge Introduction to Narrative. 2nd ed., Cambridge U P, 2008.

Anderson, Jean, Carolina Miranda, and Barbara Pezzotti. 'Introduction.' Serial Crime Fiction: Dying for More. Ed. Carolina Miranda Jean Anderson, and Barbara Pezzotti. Palgrave MacMillan, 2015, pp. 1-7.

Avis, Isadora García. 'Adapting Landscape and Place in Transcultural Remakes: The Case of Bron/Broen, The Bridge and The Tunnel.' International Journal of TV Serial Narratives, vol. 1, n 2, 2015, pp. 127-38.

Baroni, Raphaël. 'Intrigues et personnages des séries évolutives: quand l'improvisation devient une vertu.' Télévision, vol. 7, 2016, pp. 31-48.

—. La Tension narrative: suspense, curiosité et surprise. Seuil, 2007.

. 'The Many Ways of Dealing with Sequence in Contemporary Narratology.' Narrative Sequence in Contemporary Narratology. Eds. Raphäl Baroni and Françoise Revaz. The Ohio State U P, 2016, pp. 1-7.

Borges, Jorge Luis. 'Death and the Compass.' 1944. Translated by Andrew Hurley. Fictions. Penguin Books, 1998, pp. 111-23.

Brand, Dana. The Spectator and the City in Nineteenth-Century American Literature. Cambridge U P, 1991.

Brooks, Peter. Reading for the Plot: Design and Intention in Narrative. 1984. Harvard U P, 1992.

Creeber, Glen. 'Killing Us Softly: Investigating the Aesthetics, Philosophy and Influence of Nordic Noir Television.' Journal of Popular Television, vol. 3, n 1, 2015, pp. 21-35.

Danielsson, Karin Molander. The Dynamic Detective: Special Interest and Seriality in Contemporary Detective Series. Acta Universitatis Upsaliensis, 2002.

Dechêne, Antoine. Detective Fiction and the Problem of Knowledge: Perspectives on the Metacognitive Mystery Tale. Palgrave MacMillan, 2018.

Dechêne, Antoine, and Luca Di Gregorio. "'Knock It Off with the Mystical Horseshit:" Detection in the American West.' Green Letters, vol. 22, n ${ }^{\circ}, 2018$.

Eco, Umberto. 'Innovation and Repetition: Between Modern and Post-Modern Aesthetics.' Daedalus, vol. 114, nº 4 , 1985, pp. 161-84.

Esquenazi, Jean-Pierre. 'Histoires sans fin des séries télévisées.' S. \& R., vol. 1, n³9, 2015, pp. 93-102.

Even-Zohar, Itamar, Elias J. Torres Feijó, and Antonio Monegal. 'The End of Literature; or, What Purposes Does it Continue to Serve?' Poetics Today, vol. 40, n 1, 2019, pp. 7-31.

Forshaw, Barry. Death in a Cold Climate: A Guide to Scandinavian Crime Fiction. Palgrave MacMillan, 2012.

Gluck, Mary. 'The Flâneur and the Aesthetic Appropriation of Urban Culture in Mid-19th-Century Paris.' Theory, Culture \& Society, vol. 20, n5, 2003, pp. 53-80.

Hansen, Kim Toft, and Anne Marit Waade. Locating Nordic Noir. Palgrave Macmillan, 2017. Herman, David, et al. Narrative Theory: Core Concepts \& Critical Debates. Eds. Peter J. Rabinowitz James Phelan, Robyn Warhol. The Ohio State U P, 2012.

Keen, Suzanne. 'Reader's Temperaments and Fictional Character.' New Literary History, vol. 42 , n², 2011, pp. 295-314. 


\section{Crime Fiction Studies 1 (2020)}

Kelleter, Frank. 'Five Ways of Looking at Popular Seriality.' Media of Serial Narrative. Ed. Frank Kelleter. The Ohio State U P, 2017, pp. 7-34.

Kiernan, Olivia. 'Small Town Crime: A World of Possibilities.' Crimereads, 2019. Web. 05/04/2019. https://crimereads.com/small-town-crime-a-world-of-possibilities/

Merivale, Patricia, and Susan Elizabeth Sweeney, eds. Detecting Texts: The Metaphysical Detective Story From Poe to Postmodernism. U of Pennsylvania P, 1999.

Nilsson, Louise, David Damrosch, and Theo D'haen, eds. Crime Fiction as World Literature. Bloomsbury, 2017.

Piper, Paige M. 'Blood in the Snow: Mapping Murder in Contemporary Nordic/French Crime Television.' Contemporary French Civilization, vol. 43, n¹, 2018, pp. 17-31.

Poe, Edgar Allan. 'Letter to Phillip P. Cooke.' The Edgar Allan Poe Society of Baltimore 1846. Web. 28/01/2016. https://www.eapoe.org/works/letters/p4608090.htm

Priestman, Martin. 'Sherlock's Children: the birth of the Series.' The Art of Detective Fiction. Eds. Warren Chernaik, Martin Swales and Robert Vilain. Palgrave MacMillan, 2000, pp. 50-59.

Ryan, Marie-Laure. 'Cheap Plots, Plot Holes, and Narrative Design.' Narrative, vol. 17, $\mathrm{n}^{\circ} 1$, 2009, pp. 56-75.

' 'Narrative.' A Companion to Critical and Cultural Theory. Eds. Imre Szeman, Sarah Blacker and Justin Sully. Wiley-Blackwell, 2017, pp. 517-30.

- 'Story/Worlds/Media: Turning the Instruments of Media-Conscious Narratology.' Storyworlds across Media. Ed. Marie-Laure Ryan and Jan-Noël Thon. U of Nebraska P, 2014, pp. 25-49.

—. 'Texts, Worlds, Stories: Narrative Worlds as Cognitive and Ontological Concept.' Narrative Theory, Literature, and New Media: Narrative Minds and Virtual Worlds. Eds. Mari Hatavera, et al. Routledge, 2015, pp. 13-28.

Sternberg, Meir. 'Telling in Time (II): Chronology, Teleology, Narrativity.' Poetics Today, vol. 11, 1992, pp. 901-48. 
Your short guide to the EUP Journals

Blog http://euppublishingblog.com/

A forum for discussions relating to

Edinburgh University Press Journals

1. The primary goal of the EUP Journals Blog

To aid discovery of authors, articles, research, multimedia and reviews published in Journals, and as a consequence contribute to increasing traffic, usage and citations of journal content.

\section{Audience}

Blog posts are written for an educated, popular and academic audience within EUP Journals' publishing fields.

\section{Content criteria - your ideas for posts}

We prioritize posts that will feature highly in search rankings, that are shareable and that will drive readers to your article on the EUP site.

\section{Word count, style, and formatting}

- Flexible length, however typical posts range 70-600 words.

- Related images and media files are encouraged.

- No heavy restrictions to the style or format of the post, but it should best reflect the content and topic discussed.

\section{Linking policy}

- Links to external blogs and websites that are related to the author, subject matter and to EUP publishing fields are encouraged, e.g.to related blog posts

\section{Submit your post}

Submit to ruth.allison@eup.ed.ac.uk

If you'd like to be a regular contributor, then we can set you up as an author so you can create, edit, publish, and delete your own posts, as well as upload files and images.

\section{Republishing/repurposing}

Posts may be re-used and re-purposed on other websites and blogs, but a minimum 2 week waiting period is suggested, and an acknowledgement and link to the original post on the EUP blog is requested.

\section{Items to accompany post}

- A short biography (ideally 25 words or less, but up to 40 words)

- A photo/headshot image of the author(s) if possible.

- Any relevant, thematic images or accompanying media (podcasts, video, graphics and photographs), provided copyright and permission to republish has been obtained.

- Files should be high resolution and a maximum of $1 \mathrm{~GB}$

- Permitted file types: jpg, jpeg, png, gif, pdf, doc, ppt, odt, pptx, docx, pps, ppsx, xls, xlsx, key, mp3, m4a, wav, ogg, zip, ogv, mp4, m4v, mov, wmv, avi, mpg, 3gp, $3 g 2$. 